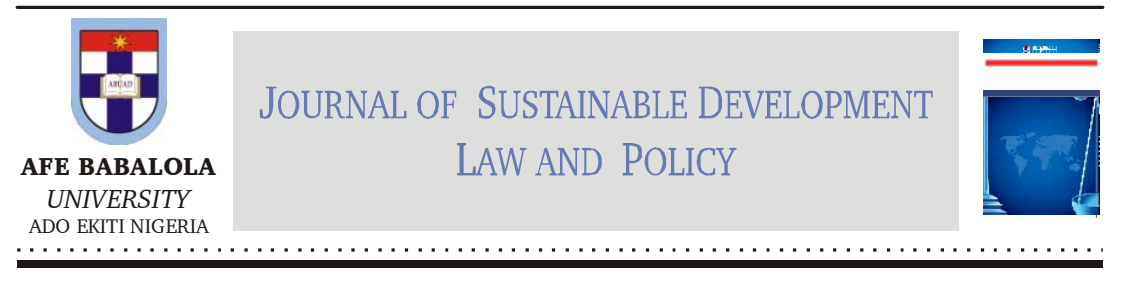

\title{
CLIMATE CHANGE AND THE SUSTAINABLE DEVELOPMENT GOAL ON FOOD SECURITY: BARRIERS AND OPPORTUNITIES FOR PROGRESSIVE REALIZATION IN QATAR AND NIGERIA
}

\author{
Idowu Ajibade* \\ Michael Egge ** \\ Arun Pallathadka***
}

\begin{abstract}
The United Nations Sustainable Development Goal 2 (SDG 2) contains a global commitment to "end hunger, achieve food security, and promote sustainable agriculture" by 2030 . The realization of this goal under the current global political economy, climate change trends, and national realities is a daunting challenge. In this article, we draw on political ecology theory to examine the complex ecological, economic, geopolitical, climatic, and socially-induced barriers that threaten the achievement of SDG 2 in two oil producing countries with a high dependency on food imports: Qatar and Nigeria. First, we provide an overview of barriers to global food security and sustainable agriculture by discussing how the unevenness of power and resource distribution, reduced genetic diversity, land grabs, restrictive property rights, and the control of stable food production by big agri-businesses, all served to undermine hunger reduction and food security in the last 20 years. Second, drawing on
\end{abstract}

* Lead author: Assistant Professor, Department of Geography, Portland State University, United States of America. Email: jajibade@pdx.edu. ORCID: 00000002-9767-0435

** Department of Geography, Portland State University, USA.

*** Department of Geography, Portland State University, USA. 
newspaper analysis and an extensive literature review, we answer the questions: what are the current and future barriers to food security in Qatar and Nigeria? What efforts are these countries taking to address these barriers? What can both countries learn from one another? We also identify opportunities for new governance architecture on local food production. Finally, we suggest ways in which crucial reforms at local, national, regional and global scales might allow these countries to progressively realize SDG 2 by 2030 even under a climate change scenario.

Keywords: Food Security; Import Dependency; Land Grab; Political Ecology; Property Rights; Sustainable Development Goals; Nigeria; Qatar.

DOI: https://dx.doi.org/10.4314/jsdlp.v10i2.2

\section{INTRODUCTION}

Food is necessary for life and plays an important role in disease prevention, social functioning, and learning capacity, among other social, cultural and health benefits. ${ }^{1}$ Food security gained global recognition during the 1974 World Food Conference where governments proclaimed that "every man, woman, and child has the inalienable right to be free from hunger and malnutrition in order to develop their physical and mental faculties". 2 This conference laid the groundwork for the World Food Summit of 1996 where global commitment was renewed at the highest political level, stating that food security "exists when all people, at all times, have physical and economic access to sufficient, safe and nutritious food to meet their dietary needs and food preferences for an active and healthy life". ${ }^{3}$ Furthermore, the 1976 International Covenant on Economic, Social, and Cultural Rights declared the "fundamental right of everyone to be free

1 Hasler, C. M, "Functional Foods: Their Role in Disease Prevention and Health Promotion. Food Technology Campaign then Chicago" (1998). See also Olawuyi D. \& Ako, R., Food and Agricultural Law (Afe Babalola University Press, 2015) 1-15; Neumann et al., "Animal Source Foods Improve Dietary Quality, Micronutrient Status, Growth and Cognitive Function in Kenyan School Children: Background, Study Design and Baseline Findings" (2003), The Journal of Nutrition, 133(11), 3941S-39495.

2 FAO, "The State of Food Insecurity in the World: Eradicating World HungerTaking Stock Ten Years after the World Food Summit" (2006) <http:// www.fao.org/docrep/009/a0750e/a0750e00.htm> (accessed September 2, 2017). 
from hunger" and acknowledged the need for international cooperation to eliminate hunger. ${ }^{4}$ These international recognitions accurately summarize the importance of food as the bedrock of life and the core reason why agriculture remains one of the most fundamental determinants of a country's overall sustainable development.

The Sustainable Development Goal 2 (SDG 2) contains a global commitment to "end hunger, achieve food security, and promote sustainable agriculture" by 2030. SDG 2 seeks sustainable solutions to achieving the tripod criteria of food security (i.e. availability, affordability, and accessibility) as a means to end hunger. Although the fight against hunger has progressed over the last decade, food security remains a distant aspiration globally. According to the UN Food and Agriculture Organization (FAO), more than 815 million people worldwide, i.e. one in nine people on earth, do not have enough food to meet their basic nutritional needs. ${ }^{5}$ Currently, Asia is the continent with the largest number of hungry people at 512 million, while Africa is second with 233 million hungry, poor and malnourished people. ${ }^{6}$ The United Nations International Children's Emergency Fund (UNICEF) also estimated that 300 million children go to bed hungry and 8000 children under the age of five die of malnutrition every day, with reported cases of malnutrition and hunger even in the developed countries such as the United Kingdom, Canada and the United States. ${ }^{7}$ Only 38 out 189 countries met the Millennium Development Goal (MDG) 1 targets for zero hunger. ${ }^{8}$ SDG 2, therefore, represents an unfinished business from MDG 1.

3 FAO (2006).

4 International Covenant on Economic Social and Cultural Rights (ICESCR), "993 U.N.T.S. 3, 6 I.L.M. 360"(1967) (entered into force Jan. 3, 1976).

5 FAO, IFAD, UNICEF, WFP and WHO, "The State of Food Security and Nutrition in the World" (2017) Building Resilience for Peace and Food Security. Rome: FAO. <http://www.fao.org/state-of-food-security-nutrition/en/> (accessed June 2, 2018).

6 Sustainable Development Knowledge Platform (SDKP), "Progress Report" (2017) $<$ https://sustainabledevelopment.un.org/sdg2> (accessed 29 May 2018). See also Olawuyi D \& Olusegun O, Achieving the United Nations Sustainable Development Goals on Biological Diversity in Nigeria: Current Issues and Future Directions (2018) Global Journal of Comparative Law 7 (1) 37-60.

7 UNICEF, "Stunting" (2016) http://unicef.in/Whatwedo/10/Stunting, (accessed March 16, 2017).

8 FAO, "38 Countries Meet Anti-Hunger Targets for 2015" (2013) Retrieved from <http://www.fao.org/news/story/en/item/177728/icode/> 
In this article, we argue that food insecurity is associated with and embedded in the social relations of production and power dynamics among and within countries. Food insecurity, therefore, cannot be addressed in an effective and sustained manner without proper interrogation of how food shortages and food crises are socially produced at multiple scales - especially how recent revolutions in law, regulatory policies, rights, and trade have accelerated the commodification of natural resources required to produce food, i.e., land, seed, air and water. Questions about hunger and food security are not different from questions about power and market economics, that is, who has power over land? Who controls seeds? Who has the capacity to respond to changes in climatic conditions and market prices? Who controls agricultural systems? How is power over food and agricultural systems legitimized through power structures and global market forces that create a perpetual system of winners and losers? These questions remain salient as the world calculates the gains and losses from the MDGs, but also looks forward to meeting the SDGs. Using Nigeria and Qatar as case studies, we explore some of these problems and other barriers that might undermine the progressive realization of SDG 2 in both countries.

Following this introduction, we provide an overview of SDG 2 and contextualize it within a political ecology and theoretical framework. We show that food is embedded in the broader political economy and central to the understanding of political ecologies of land relations, agrarian change, and environmental norms and practices in the vast majority of societies in the world. To this effect, we argue that new global goals such as SDG 2 are unlikely to produce sustainable socioenvironmental futures to the extent that they fail to account for problems in the global political economy, national and regional differences, and local transformations that affect the drivers and underlying root causes of food insecurity. After the theory section, we briefly discuss lessons learnt in the last fifteen years and identify the transformation required on a global scale moving forward. In the subsequent section, we focus on our case studies of food security challenges in Nigeria and Qatar. We discuss the peculiar barriers that each country faces, their strategies for overcoming these barriers, and other reforms required to facilitate the progressive implementation of SDG 2. We conclude this article with recommendations to governments and policy makers on the transformation and synergy required to ensure sustained results on SDG 2 targets in developing and emerging economies. 


\section{SDG 2 AND POLITICAL ECOLOGIES OF GLOBAL FOOD SECURITY}

The United Nations General Assembly adopted the SDGs in September 2015 to replace the previously established Millennium Development Goals (MDGs) (2000-2015). The SDGs are far more expansive than the MDGs. There are 17 SDGs with 169 targets, covering a broad range of sustainable development issues, including poverty eradication, reduced inequality, clean water and sanitation, clean energy, climate action, and so on. SDG 2 specifically contains significant and ambitious commitments to ensure that everyone everywhere has enough good quality food to lead a healthy life. ${ }^{9}$ Its ultimate aim is to end hunger and all forms of malnutrition by the year 2030 through sustainable food production systems and resilient agricultural practices. In this article, we argue that a politicized understanding of food security and agricultural systems is a first step in an emancipatory effort to challenge the current status quo as a way to change it. To do this, we use political ecology theory to examine the architecture of global food insecurity and its implications for poor countries and communities.

Political ecology is defined as the combination of ecological concerns and a broadly defined political economy. It emerged in the 1970s as a critique of the apolitical understanding of the relationship between food, famine, environmental change, and land degradation. ${ }^{10}$ Studies in this area have used a Marxist historical perspective to critically examine how food insecurity and famine are socially produced through the incorporation of agrarian communities into the global capitalist economy, particularly exploring the role of the state in supporting accumulation by dominant classes - both local and transnational. ${ }^{11}$ While acknowledging environmental constraints, political ecologists have rejected the

9 UNDP, "Qatar: Human Development Indices and Indications: 2018 Statistical Update" (2018) < http://hdr.undp.org/sites/all/themes/hdr_theme/countrynotes/QAT.pdf $>$

10 Watts M, "Silent Violence Food, Famine, and Peasantry in Northern Nigeria" (University of Georgia Press 1983) See also Blaikie and Brookfield, "Land Degradation and Society" (Routledge 1987).

11 Watts M, (1983); See also Neumann, C. G., Bwibo, N. O., Murphy, S. P., Sigman, M., Whaley, S., Allen, L. H., \& Demment, M. W., "Animal Source Foods Improve Dietary Quality, Micronutrient Status, Growth and Cognitive Function in Kenyan School Children: Background, Study Design and Baseline Findings" (2003) The Journal of Nutrition, 133(11), 3941S-3949S. 
Malthusian narrative of resource scarcity as the underlining cause of food insecurity. Instead, scarcity is seen as a result of inequalities produced through systems of food governance, markets, and distribution. ${ }^{12}$ For example, Sen (1981) showed that the 1943 West Bengal famine was caused by well-functioning markets, not drought or absolute shortage in food supplies. More recently, scarcity discourses have attempted to naturalize existing inequalities and have been used by neoliberal proponents to enter into fragile markets for the purpose of capital accumulation. Political ecologists, drawing on chains of explanation and scalar analysis, have therefore dismissed mainstream accounts that blame local people or non-human actors (such as drought, floods, and climatic conditions) as the root cause of food insecurity. ${ }^{13}$ Rather, focus is shifted to how land and resource use decisions are shaped by political and economic forces that operate at scales that transcend the local level. ${ }^{14}$ For example, climate change, which has become an important factor in food production, has roots in industrial revolution and well-functioning capitalist markets that have contributed to transforming the global environment in radical ways with severe implications for sustainable agriculture both in developed and developing countries.

In analysing modern agriculture and food systems in developing regions, a number of scholars have shown that a variety of factors drive food security, including neoliberal policies and the effects of deregulation; the weakening power of government institutions; the growing influence of corporate power; class and gender relations in agriculture; ecological conditions and consequences of different forms of agricultural practices. Also important is the complex restructuring of trade relations including new forms of valuation and commodification of nature and their profound implications in terms of who is able to produce food, who is able to access food, and who is able to choose what they eat and how much they eat. ${ }^{15}$ Viewed from this perspective, achieving global and national

12 Sen, A, "Ingredients of Famine Analysis: Availability and Entitlements" (1981) The Quarterly Journal of Economics，96(3), 433-464. See also Bohle et al., "Climate Change and Social Vulnerability: Toward a Sociology and Geography of Food Insecurity" (1994) Global Environmental Change, 4(1), 37-48.

13 Sen, A. (1984), Watts M (1983).

14 Bryant, R. L \& Bailey, S “Third World Political Ecology” (Routledge 1997) See Also Robbins, P. "Political Ecology: A Critical Introduction", Vol. 16 (John Wiley \& Sons 2012).

15 Patel, R, "Food Sovereignty" (2009). The Journal of Peasant Studies, 36(3), 663 706. See also Hall, D "The Political Ecology of International Agri-Food Systems" (Routledge 2015). The Routledge Handbook Of Political Ecology. 
food security as well as sustainable agriculture thus becomes a mosaic of power structures, economic relations, land use, property rights, and ecological transformations involving different methods of commandeering the natural environment, normative visions of development, and valuation systems about food. In this article, we argue that global goal setting, while important, also obscures the social processes through which food security or insecurity is produced. To gain a holistic understanding of the challenges ahead in realizing SDG 2, attention, therefore, must be given to global, regional and national political economy forces, including issues of uneven power relations among and within states, changes in climatic conditions, disturbance of local ecologies, social relations of power, as well as interactions and influences of the global food market and price mechanisms.

In the subsequent section, we provide an overview of lessons learned in the last 20 years. We also discuss the need to avoid a similar pitfall in the 15 years dedicated to achieving SDG 2 .

\section{WHAT WE HAVE LEARNT ON A GLOBAL SCALE IN THE LAST 20 YEARS}

When the MDGs ended in 2015, it received commendation for reducing extreme poverty and hunger rates. The United Nations reported a 50 per cent reduction in the number of people living in extreme poverty and hunger. In developing regions, the proportion of people living on less than US $\$ 1.25$ a day fell from 47 per cent to 22 per cent by 2010 , and the proportion of undernourished people globally decreased from 23.2 per cent in 1990 to 14.9 per cent in 2012 (United Nations, 2015). Critics, however, expressed that progress on hunger reduction was less than it appeared. ${ }^{16}$ Global rates masked uneven regional and national progress in reducing hunger. China's successful poverty reduction strategy, for example, accounted for most of the world's gain over the last 25 years. ${ }^{17}$ Extreme poverty rates in East Asia, which dropped from 61 per cent in

16 Pingali, P. L, “Opinion: The Hunger Metrics Mirage: There’s Been Less Progress on Hunger Reduction than It Appears" (2016). Proceedings of the National Academy of Sciences, 113(18), 4880-4883.

17 Permanyer, I, "The Measurement of Success in Achieving the Millennium Development Goals" (2013) The Journal of Economic Inequality, 11(3), 393415. See also United Nations "The Millennium Development Goals Report" (2015). <http://www.un.org/millenniumgoals/2015_MDG_Report/pdf/ MDG\%202015\%20rev\%20(July\%201).pdf 
1990 to 4 per cent in 2015, were also part of the gains. In contrast, 40 per cent of the population in sub-Saharan Africa remained in extreme poverty with millions of people unable to afford a daily meal. ${ }^{18}$

A major concern within the last 20 years was the strategic move to impose genetically modified (GM) seeds on variety of countries desperate for food. These seeds are owned by transnational agri-businesses seeking new markets for surplus extraction. Some scholars have argued that the move to GM seeds is necessary to address global food insecurity because of increased population growth and the need to respond to climate change. ${ }^{19}$ As a result, biotechnology-market solutions backed by Malthusian narratives are being used to validate and legitimize the production of GM corns and soybeans as the main staple to feed the world's population. This has led to major restructuring in seed ownership and increased monopoly of seed markets by agri-businesses such as Monsanto, Dupont, and Sygenta. For example, Monsanto controls 80 per cent of GM corn market, 93 per cent of GM soybeans market, and over 282 million acres of land worldwide are being used to grow GM products. ${ }^{20}$ Such levels of concentration of corn and soybeans in the hands of big businesses has led to reduced genetic diversity, fewer choices for farmers, and skyrocketing prices regardless of whether farmers choose to grow GM or organic (Non-GM) seeds. ${ }^{21}$

Furthermore, the question of who owns, has legitimate rights over, and controls or uses seeds is important when thinking about SDG 2. In the last decade, transnational agri-businesses have gained greater control over global seeds and indigenous people's knowledge through new property rights protected by Patent Laws and the Trade-Related Intellectual

18 United Nations “The Millennium Development Goals Report” (2015). <http:// www.un.org/millenniumgoals/2015_MDG_Report/pdf/MDG\%202015\%20 rev\%20(July\%201).pdf>

19 Phipps, R. H., \& Park, J. R., "Environmental Benefits of Genetically Modified Crops: Global and European Perspectives on Their Ability to Reduce Pesticide Use" (2002) Journal of Animal and Feed Sciences, 11(1), 1-18. See also D Olawuyi, Principles of Nigerian Environmental Law (Afe Babalola University Press, 2015) 324-336.

20 Howard, P. H., "Visualizing Consolidation In The Global Seed Industry: 19962008" (2009) Sustainability, 1(4), 1266-1287. See also Roseboro, K., "The GMO Seed Cartel" (2013) The Organic and Non- GMO Report.

21 Hubbard, R. \& Navarro, P., "Seeds of destruction: Why the Path to Economic Ruin Runs through Washington, And How to Reclaim American Prosperity" (FT Press 2010). 
Property Rights (TRIPS) Agreement of the World Trade Organization. ${ }^{22}$ Seed, once a common property, is now transformed through bio-technology and global intellectual property and patent laws into a private commodity to enhance surplus extraction from some of the most vulnerable regions of the world. This form of appropriation implies new valuation systems and transfer of ownership of resources (that were once public or not even subject to ownership) into the hands of the powerful. ${ }^{23}$ For Shiva (2016), "patents on seeds is a patent on life", by adding one new gene to the cell of a plant, corporations lay claim to the invention of a new seed, a new plant, and all future seeds, as their private property conferring exclusive rights to the owners. ${ }^{24}$ Not only are seed patents extremely expensive but those that profit the most are the transnational agribusinesses. For example, between 2004 and 2008, Monsanto and Dupont accounted for 60 per cent of patent applications. ${ }^{25}$ By 2007, Monsanto owned 23 per cent of global proprietary seed market; Dupont owned 15 per cent; and Syngenta 9 per cent. ${ }^{26}$ Since then, new mergers and acquisitions of the seed market have occurred, and the number of patents owned by these companies has increased, thus concentrating seed ownership in the hands of capital. David Harvey describes such economic re-structuring as "accumulation by dispossession" 27 - where smallholder farmers are now forced to purchase seed from the "new owners". This process of accumulation underlies global food insecurity and unsustainable agricultural practices. Patents of seeds impoverish human society ethically, economically, and ecologically. They deserve further interrogation under the SDG 2, especially if the least developed countries are to achieve food security by 2030 .

Other problems that emerged in last 20 years included land grabbing,

22 Shiva, V., "Biopiracy: The Plunder of Nature and Knowledge" (North Atlantic Books 2016).

23 Fairhead, J., Leach, M., \& Scoones, I., "Green Grabbing: A New Appropriation of Nature?" (2012) Journal of Peasant Studies, 39(2), 237-261.

24 Shiva, V (2016)

25 Pardey, P., Koo, B., Drew, J., Horwich, J., \& Nottenburg, C., "The Evolving Landscape of Plant Varietal Rights in the United States" (2013) 19302008. Nature Biotechnology, 31(1), 25.

26 GMwatch, "The World's Top 10 Seed Companies: Who Owns Nature?" (2009) $<$ https://www.gmwatch.org/en/gm-firms/10558-the-worlds-top-ten-seedcompanies-who-owns-nature $>$ (accessed May 30, 2018).

27 Harvey, D. "The New Imperialism” (OUP Oxford 2003). 
food price volatility, geopolitical conflicts, increases in extreme weather events, decreases in soil fertility, and food justice issues on multiple scales. We discuss some of these concerns in our case study of Nigeria and Qatar and argue that SDG 2 presents a possibility of conceiving food security in radically different ways that ensures equity and justice in production, availability and access.

\section{COUNTRY ANALYSIS OF FOOD SECURITY AND SDG 2}

To give an illustration of the existing and new challenges developing countries face in achieving food security and meeting SDG 2, we focus on two case studies: Nigeria and Qatar. We draw on an extensive literature review and newspaper analysis in Nigeria and Qatar. Both countries were selected based on their similarities and peculiar struggles with food security. Both countries have a history of a sluggish agricultural sector; they run oil and gas-based economies; they are members of the Organization of Petroleum Exporting Countries (OPEC); they rely heavily on food imports; and are predicted to experience severe climate change impacts. However, there are differences in terms of population, GDP, natural resources, water availability, climate, and forest cover.

\subsection{Food Security in Nigeria}

Nigeria is the most populous country in Africa with about 190.9 million people. ${ }^{28}$ It has a total land mass of $923,763 \mathrm{~km}^{2}$ and is diverse both culturally and geographically with a wide range of natural resources. About 60 per cent of the land in the country (74 million hectares) is arable with variations between the North and South. In the early 1950s, Nigeria fed its population and was a major exporter of food. ${ }^{29}$ However, the discovery of oil and the military takeover in the 1970s led to decreased investment in agriculture and greater dependency on oil revenue that would continue for several years. Riding on the accruing petrodollars,

28 United Nations Data, "World Population prospects 2017" (2017). <http:// data.un.org $/$ Data.aspx? $\mathrm{q}=$ nigeria $\& \mathrm{~d}=$ PopDiv $\& \mathrm{f}=$ variableID $\% 3 \mathrm{a} 12 \%$ 3bcrID\%3a566>

29 Onafeso, O. D., Akanni, C. O., \& Badejo, B. A., "Climate Change Dynamics and Imperatives for Food Security in Nigeria" (2015) Indonesian Journal of Geography, 47(2), 151-159. 
Nigeria's economy has grown in the last five decades. Its Gross Domestic Product (GDP) is US $\$ 375.8$ billion and Gross National Income (GNI) per capita is US\$5,700. ${ }^{30}$ However, the country struggles to meet the basic needs of its citizens. Nigeria also ranks low on the UN Human Development Index at 157 out of 189 countries; and the proportion of working people who live on less than US\$3 a day is 71.7 per cent. ${ }^{31}$ During the MDG timeline, Nigeria did not significantly reduce poverty but made progress in the fight against hunger. It reduced hunger by 66 per cent and also reduced the proportion of underweight children from 35.7 per cent in 1990 to 25.5 per cent in $2013 .{ }^{32}$ This progress was achieved through a combination of institutional and policy interventions such as the Agriculture Transformation Agenda (ATA) implemented by the Federal Ministry of Agriculture, the National Poverty Eradication Programme (NAPEP) and several other development partners. ${ }^{33}$

Recent data shows Nigeria has not been able to maintain success on hunger reduction. In 2017, the country fared poorly on the Global Hunger Index ${ }^{34}$ with a composite score of 25.5 and a ranking of 84 out of 119 developing countries. ${ }^{35}$ Nigeria was also listed among countries with imminent famine warnings due to drought, starvation, and escalated violent conflict in the northern part of the country. In the North East, 4.5 million Nigerians are at the risk of famine while female-headed households are more food insecure than others. ${ }^{36}$ In the section below we discuss the political, economic, social, and environmental factors affecting food availability, affordability and accessibility in Nigeria. We

30 World Bank, "GNI per capita: Nigeria" (2018). https://data.worldbank.org/ indicator/NY.GNP.PCAP.CD?locations $=$ NG.

31 UNDP, "Human Development Indicators: Nigeria" (2017) <http:// hdr.undp.org/en/countries/profiles/NGA>

32 United Nations Programme (UNDP), "Nigeria 2015: Millennium Development Goals, End-Point Report" (2015a) < http://www.undp.org/content/dam/undp/ library/MDG/english/MDG\%20Country\%20Reports/Nigeria/ Nigeria_MDGs_Abridged_Sept30.pdf >

33 United Nations Programme (2015a).

34 GHI Score Is Calculated Based on the Proportion of Undernourished Population, the Prevalence of Wasting and Stunting in Children under Five Years, and UnderFive Mortality Rate.

35 Global Hunger Index (GHI), "Global Hunger Index:2017" (2017) <https:// fscluster.org/sites/default/files/documents/global_hunger_index_2017.pdf>

36 FEWS NET, "Nigeria: Severe Acute Food Insecurity Persists in the Northeast as Lean Season Begins" (2017) < http://fews.net/west-africa/nigeria > (accessed January 2019). 
pay attention to how power structures, social and economic relations, land rights, and ecological transformation will affect the country's potentials to achieve SDG 2.

\subsubsection{Barriers to Food Security in Nigeria}

\subsubsection{Climate Change, Bad Harvests, and Dysfunctional Markets}

Like most African countries, Nigeria relies heavily on rain-fed agriculture, which is becoming more precarious due to climate change. In Southern Nigeria, climate-related flooding destroys farms every year while drought conditions compounded by the lack of irrigation affect food production in the North. ${ }^{37}$ Desertification is also wiping out plants, animals and freshwater resources, thus pushing people to further encroach on the few parcels of forest left in the North. ${ }^{38}$ Furthermore, lower yields brought about by the combination of high temperatures, less rainfall, and shrinking lakes are a significant cause of poor harvest. Lower yields mean less food for consumers and lower returns on farmers' investments. In other words, they are less able to afford setting up for next planting season and are increasingly forced to abandon their farms to find work in other sectors, ${ }^{39}$ thereby decreasing food production and availability.

\subsubsection{Power Politics, Conflicts, and Food Accessibility}

While droughts, arid conditions, and natural disasters can bring about famine, politics and internal strife can exacerbate such conditions. In Nigeria's predominantly farming areas of the Middle Belt Region, violent clashes between farmers and herdsmen have resulted in the destruction of lives and farmlands, threatening food security. ${ }^{40}$ Climate change and the expanding Sahara desert are reducing grazing land in Northern Nigeria, forcing herdsmen further south where they come into conflict with farmers and their land. Some states have tried to address this problem

37 Bello, O. B., Ganiyu, O. T., Wahab, M. K. A., Afolabi, M. S., Oluleye, F., Mahmud, J. \& Abdulmaliq, S. Y., "Evidence of Climate Change Impacts on Agriculture and Food Security in Nigeria" (2012) International Journal of Agriculture and Forestry, 2(2), 49-55.

38 Bello et al (2012).

39 Bello et al (2012).

40 Eme, O. I., Onyishi, A. O., Uche, O. A., \& Uche, I. B., "Food Insecurity In Nigeria: A Thematic Exposition" (2014) Arabian Journal of Business and Management Review (OMAN Chapter), 4(1), 1. 
by passing anti-open grazing laws, but this has driven more herdsmen into states without these laws, thus escalating conflicts in those areas. Added dimensions to the land use struggle are religious and ethnic tensions: the herders are predominantly Muslims and farmers Christians from a different ethnicity group. The President Muhammadu Buhari government has done very little to intervene in the conflicts. Some scholars blame this on a conflict of interest since the president is from the same ethnicity as the herders. ${ }^{41}$ Moreover, Boko Haram is suspected of playing both sides against one another to stir up further unrest. ${ }^{42}$ Militant activities in this area have slowed down the rate of production, thereby creating food shortages and hurdles with accessibility - as fear prevents people from going to their farms and keeping aid organizations from reaching those in need of food (UNDP 2017). This problem is further exploited by Boko Haram; the group uses food shortages as a recruitment tool - promising disaffected, starving Nigerians food in exchange for enlistment, creating a vicious cycle that will not be resolved on its own without intervention from the Nigerian government. ${ }^{43}$

The crisis in Northern Nigeria impacts the whole nation. Urban areas such as Lagos enjoyed relative food availability before the conflict became full blown. The North supplies Lagos with 90 per cent of its food and markets such as Ketu, Mile 12, and Oyingbo got their produce from northern states daily before Boko Haram infiltrated the area, ${ }^{44}$ thereby creating fear and destabilizing supply. These issues show how political conundrums and conflicts in one part of the country could have reverberating effects nationwide, thereby affecting overall food security.

\subsubsection{Weak Regulatory Regime, Land Grabbing and Sustainable Agriculture}

Power politics can be seen in the minimal support provided to smallholder farmers' vis-à-vis big capital. On the one hand, farmers in Nigeria lack supplies, including water, vehicles, tools, fuel, fertilizer, seeds, land,

41 Eme et al (2014).

42 International Crisis Group, "Stopping Nigeria's Spiralling Farmer-Herder Violence" (2018). < https://www.crisisgroup.org/africa/west-africa/nigeria/ 262-stopping-nigerias-spiralling-farmer-herder-violence $>$

43 CIA, "The World Factbook: Nigeria" (2018) < https://www.cia.gov/library/ publications/the-world-factbook/geos/ni.html>

44 Eme, O. I., Onyishi, A. O., Uche, O. A., \& Uche, I. B., "Food Insecurity in Nigeria: A Thematic Exposition" (2014) Arabian Journal of Business and Management Review (OMAN Chapter), 4(1), 1. 
training, education, and legal protection, which in turn affects their ability to scale-up food production. On the other hand, the few lands available to farmers are being threatened by the current wave of land grabs going on across the country. Land grabbing is a large-scale acquisition (buying or leasing) of land in developing countries by domestic and transnational companies, government, and individuals for different purposes, including biofuel production, food, financial security, and ecotourism. ${ }^{45}$

This is often done with little regard for local communities' rights to land, food, livelihood, and environmental sustainability. Such land appropriation has occurred in almost all 36 states of Nigeria - where the federal government, represented by Nigerian National Petroleum Corporation (NNPC) and their foreign partners, have acquired land to produce agro-fuel despite being one of the leading producers of oil in the world. ${ }^{46}$ Biotech companies producing GM crops have also increased their presence and participation in land grabs in Nigeria with new research into genetically modified forms of cassava, sorghum, cowpea and rice. ${ }^{47}$ This latter issue has implications for seed ownership and control. There are also large-scale land deals for Jathropha, an agro-fuel, which could dispossess smallholder farmers from their land, reduce investment in food crops, and undermine sustainable agriculture.

\subsubsection{Food Importation, Affordability, and Safety}

Food prices have soared across Nigeria, but household income has not kept pace. ${ }^{48}$ A basket of tomatoes that was sold for N300-N500 in 2004

45 Fairhead, J., Leach, M., \& Scoones, I., "Green Grabbing: A New Appropriation of Nature?" (2012) Journal of Peasant Studies, 39(2), 237-261; See also GRAIN, "The 2008 Land Grab for Food and Financial Security" (GRAIN 2008) < https:/ /www.grain.org/article/entries/93-seized-the-2008-landgrab-for-food-andfinancial-security > (accessed Jan 20, 2019).

46 Attah, N. E., "Possession by Dispossession: Interrogating The New Wave of Land Grabbing in Nigeria" (2013) Journal of Land and Rural Studies, 1(2), 213-228.

47 Cerier S, "Led by Nigeria, Africa Opening Door To Genetically Modified Crop Cultivation" (2017) < https://geneticliteracyproject.org/2017/03/06/lednigeria-africa-gradually-opening-door-genetically-modified-crop-cultivation/>

48 Eme, O. I., Onyishi, A. O., Uche, O. A., \& Uche, I. B., "Food Insecurity in Nigeria: A Thematic Exposition" (2014) Arabian Journal of Business and Management Review (OMAN Chapter), 4(1), 1. 
became N7,000-N9,000 by $2014 .{ }^{49}$ The latter is not affordable to most Nigerians who live on less than N1.088 per day. Several factors affect food prices in Nigeria, including the lack of infrastructure, corruption, conflict, fluctuation in oil prices, and transportation cost associated with moving food from the North to the South. The Federal Government's response to food shortages and the consequent rise in prices has been to increase food imports using oil revenue..$^{50}$ Nigeria spends over a trillion naira annually on food imports: N635 billion on wheat; N356 billion on rice; N217 billion on sugar; and N97 billion on fish. ${ }^{51}$ This creates an additional financial burden for the country while increasing vulnerability to price volatility in the global market. Food importation also has safety implications, especially when they come from countries with low safety standards such as China. Due to high tariffs, many food imports, including rice, are smuggled illegally through Cameroon, Ivory Coast, and Benin, without proper check for their safety. A number of people have died of food poisoning in the recent years; food regulation and control are low. For example, expiry dates are re-stamped to increase sales past actual recommendation by producers.

The combined structural and socially induced problems discussed in the section are, in part, responsible for food insecurity in Nigeria. The SDG 2 offers a new opportunity to revisit these concerns and to re-appraise Nigeria's food security strategy.

\subsection{Overview of Food Security in Qatar}

Unlike Nigeria, Qatar is a relatively small country with a land mass of $11,570 \mathrm{~km}^{2}$ and a population of 2.6 million people; made up of over 80 per cent immigrants. ${ }^{52}$ It is one of the richest in the world owing to its oil reserves and its increasing economic diversification. ${ }^{53}$ Qatar's Human

49 Eme et al (2014).

50 Ojo, E. O., and Adebayo, P. F., "Food Security in Nigeria: An Overview" (2012) European Journal of Sustainable Development 1(2):199-222.

51 Onafeso, O. D., Akanni, C. O., \& Badejo, B. A., "Climate Change Dynamics and Imperatives for Food Security in Nigeria" (2015) Indonesian Journal of Geography, 47(2), 151-159.

52 Qatar Economics, (2018) Retrieved on 15 December 2018, from <https:// tradingeconomics.com/qatar/employed-persons>

53 Sippel, S., \& Kemmerling, B. "Power Geometries of Food Security: A Critical Area Studies Perspective" (2013) In: Middell, M. Self-Reflexive Area Studies 215247. 
Development Index (HDI) value for 2017 is 0.856 which puts the country in the high human development category - positioning it at 37 out of 189 countries and territories. ${ }^{54}$ Qatar's GDP is US $\$ 167.6$ billion and its GNI per capita on PPP is US $\$ 116,818 .{ }^{55}$ Unemployment is consistently low, reported at a 0.10 per cent rate in $2018 .{ }^{56}$ Qatar attained MDG 1 around 1990 using the UN benchmark of US $\$ 1.25 .{ }^{.7}$ However, the country has one of the harshest climates on earth with 1.1 per cent arable land, low soil fertility, and severe water scarcity. ${ }^{58}$ Also, it receives little rain throughout the year - $71 \mathrm{~mm}$ per year on average - and its aquifers are depleted. ${ }^{59}$ Despite these constraints, the country ranks high at 76.5 composite score on the Global Food Security Index: covering affordability, availability, quality and safety. ${ }^{60}$ Behind these glossy figures is a heavy reliance on food imports, which presents significant challenges to longterm food security under the SDGs. We discuss the barriers Qatar faces on food security in the section below; including some of the politically contested solutions it is taking to address its food security problems.

\subsubsection{Barriers to Food Security in Qatar}

\subsubsection{Climate Change, Import Dependency and Food Prices}

Achieving food security has not always been easy for Qatar. Given its arid climate and limited water supply, the country produces very little of its own food. In fact, over the last decade, climate change has further exacerbated these conditions by intensifying the cycle of water scarcity, causing drier weather and consequent reduction in agricultural yields,

54 UNDP. "Qatar: Human Development Indices and Indications: 2018 Statistical Update" (2018) < http://hdr.undp.org/sites/all/themes/hdr_theme/countrynotes/QAT.pdf $>$

55 UNDP (2018)

56 Qatar Economics (2018).

67 UNDP, "The Arab Millennium Development Goals Report" (2015b). <http:// www.undp.org/content/dam/rbas/doc/MDGS\%20publications/ Arab_MDGR_2013_English.pdf>

58 Kamrava, M., "Qatar: Small state, big politics"(Cornell University Press 2015).

59 Gastli, A., Charabi, Y., Alammari, R. A., \& Al-Ali, A. M., "Correlation between Climate Data and Maximum Electricity Demand in Qatar" (2013) In GCC Conference and Exhibition (GCC), 2013 7th IEEE (pp. 565-570). IEEE

60 Global Food Security Index (GFSI) Ranking and Trends, "GFSI Ranking" (2018). $<$ https://foodsecurityindex.eiu.com/Index > 
forcing the country to near total dependence on the global food market. ${ }^{61}$ Technological fixes, such as irrigation and desalination, have been the options open to Qatar to improve its local food production; however desalination requires large capital inputs and leads to high food prices. Food importation was, therefore, a cheaper and more feasible option. Qatar imports about 90 per cent of its food from several countries. ${ }^{62}$ For example, between 1998 and 2017, Qatar spent QAR 105.78 billion on food imports comprising mainly of meats, cereals, dairy and vegetables. ${ }^{63}$ Although the food importation has been less of a financial burden, ${ }^{64}$ it remains a political nightmare. ${ }^{65}$ Threats of trade embargos and dependency on foreign imports produce a keen awareness of the country's fragility. ${ }^{66}$ This awareness heightened during the 2008 global food crisis when prices escalated, and food supply was dramatically cut short as countries imposed temporary export bans on food. During this period, daily staples such as milk and cereal became unaffordable, especially for low-income migrant workers. ${ }^{67}$ Qatar's tenuous relationship with Saudi Arabia and Iran made it difficult for the country to weather the sociallyinduced food crisis, thus prompting a re-appraisal of the country's food security strategy. ${ }^{68}$

61 Sippel, S., \& Kemmerling, B. "Power Geometries of Food Security: A Critical Area Studies Perspective” (2013) In: Middell, M. Self-Reflexive Area Studies 215247.

62 Miniaoui H, Irungu P, and Kaitibi S, "Contemporary Issues in Qatar's Food Security" (2018) Middle East Insights No. 185. Middle East Institute, National University Singapore <https://mei.nus.edu.sg/publication/insight-185contemporary-issues-in-qatars-food-security/>

63 Miniaoui, et al., (2018).

64 Klingbeil, R., \& Byiringiro, F., "Food Security, Water Security, Improved Food Value Chains for a more Sustainable Socio-economic Development" (2013) https://doi.org/10.13140/2.1.2616.1443

65 Woertz, E., "The Governance of Gulf Agro-Investments" (2013) Globalizations, 10(1), 87-104 <https://doi.org/10.1080/14747731.2013.760932>

66 Woertz (2013).

67 Fottrell, S., "Qatar Workers' 'Pathetic' Conditions" (BBC News 2015, May 21) Retrieved from < https://www.bbc.com/news/world-middle-east-32822016>

68 Klingbeil, R., \& Byiringiro, F., "Food Security, Water Security, Improved Food Value Chains for a More Sustainable Socio-economic Development" (2013) <https://doi.org/10.13140/2.1.2616.1443>; See also Mustafa, S. A.-A., "Growing Food Pyramids in the Sand: How Sustainable Are Qatar's SelfSufficiency and Foreign Agro-Investment Policies?" (2017) Journal of Agriculture and Environment for International Development 2(111), 409-424. 


\subsubsection{Self-Sufficiency and Land Acquisitions}

Following the 2008 food crisis, therefore, Qatar developed an interest in achieving self-sufficiency. The government introduced the Qatar National Food Security Programme (QNFSP) in 2009 with the aim of increasing self-sufficiency from 10 per cent to 70 per cent by 2023. Ambitions were lowered to 40 to 60 per cent in a later version of the plan. This programme, finalized in 2013, set goals to increase independence, foreign investments, and trade agreements to achieve greater food security. ${ }^{69}$ Within this framework, Qatar also considered water security, energy consumption, and international and public-private partnerships. ${ }^{70}$ Domestically, Qatar seeks to update its food processing regulations and practices, thus increasing the quality of food entering its market while decreasing food waste. ${ }^{71}$ Furthermore, the QNFSP aims to produce its own food by dramatically increasing its domestic production through hydroponics, greenhouses, and desalinization. ${ }^{72}$ Such plans have been criticized as hopeful at best, given the financial and ecological challenges to agricultural production in the region. ${ }^{73}$ Water security is also a barrier as aquifer use is unsustainable while desalinization has significant environmental, financial, and social costs.

As part of its food security strategy, Qatar continues to rely on imports but has also increased its foreign agricultural investments. ${ }^{74}$ It invests in

69 Mustafa, S.A.-A., "Growing Food Pyramids in the Sand: How Sustainable Are Qatar's Self-Sufficiency and Foreign Agro-Investment Policies?" (2017) Journal of Agriculture and Environment for International Development 2(111), 409-424.; See also Woertz, E., "The Governance of Gulf Agro-Investments" (2013) Globalizations, 10(1), 87-104 <https://doi.org/10.1080/14747731. 2013.760932>

70 Mustafa, S.A.-A. (2017).

71 Suresh, S., "Food Security Strategy in Qatar" (2017, March 8). Retrieved 22 December 2018 from https://www.ecomena.org/food-security-qatar/.

72 Woertz (2013).

73 Ismail, H., "Food and Water Security in Qatar: Part 1 - Food Production (Global Food and Water Crises)" (2015) Nedlands, AU: Future Directions International. Retrieved from <http://www.futuredirections.org.au/publication/food-andwater-security-in-qatar-part-1-food-production/>

74 Ismail, H., "Food and Water Security in Qatar: Part 1 - Food Production (Global Food and Water Crises)" (2015) Nedlands, AU: Future Directions International. Retrieved from < http://www.futuredirections.org.au/publication/food-andwater-security-in-qatar-part-1-food-production/ > ; See also Mustafa, S.A.-A., "Growing food pyramids in the sand: how sustainable are Qatar's self-sufficiency and foreign agro-investment policies?" (2017) Journal of Agriculture and Environment for International Development 2(111), 409-424. 
farmland acquisitions and operations in foreign countries. ${ }^{75}$ This reduces the reliance on the world market and is therefore less prone to price fluctuations. ${ }^{76}$ Hassad Food Company (HFC), Qatar's sovereign wealth fund for foreign agro-investments, was established in 2008 to facilitate land acquisition and increase food production and supply. HFC operates farms in Qatar, Australia, Oman, Sudan, Pakistan, and is considering expanding to Kenya, Brazil, Argentina, Turkey, and Ukraine. As of 2017, HFC owns a quarter of a million hectares of agricultural land in Australia where it produces sheep and wheat. ${ }^{77}$ Qatar wields significant wealth and power that allows it meet its food security goals through land acquisition abroad. However, this also raises questions about the impact of such acquisitions on smallholder farmers in poor countries such as Pakistan, Kenya, and Ethiopia; similar to the land grabbing trend in Nigeria. There is also potential effect on local production and food availability in those nations. ${ }^{78}$

\subsubsection{Geopolitical Struggles and Food Disruption}

Prior to the 2017 boycott, Saudi Arabia and the United Arab Emirates (UAE) were Qatar's important trade partners. About 40 per cent of Qatar's food imports enter through the border of Saudi Arabia. This puts Qatar at the mercy of regional geopolitical struggles. In 2017, a Saudi Arabialed coalition, which included the UAE, Bahrain, Egypt, among others, severed diplomatic relations with Qatar and imposed an air, sea, and land blockade that prevented the importation of food and other goods. ${ }^{79}$

75 Lawrence, G., Richards, C., \& Lyons, K., "Food Security in Australia in an Era of Neoliberalism, Productivism and Climate Change" (2013) Journal of Rural Studies, 29, 30-39. < https://doi.org/10.1016/j.jrurstud.2011.12.005>; See also Sippel, S., \& Kemmerling, B., "Power Geometries of Food Security: A Critical Area Studies Perspective" (2013) In: Middell, M. Self-Reflexive Area Studies 215247.

76 Larder, N., Sippel, S. R., \& Lawrence, G., "Finance Capital, Food Security Narratives and Australian Agricultural Land" (2015) Journal of Agrarian Change, 15(4), 592-603; See also Sippel, S., \& Kemmerling, B, (2013).

77 Miniaoui H, Irungu P, and Kaitibi S, "Contemporary Issues in Qatar's food Security" (2018) Middle East Insights No. 185. Middle East Institute, National University Singapore <https://mei.nus.edu.sg/publication/insight-185contemporary-issues-in-qatars-food-security/>

78 Lawrence et al (2013).

79 Al Jazeera, "Qatar-Gulf rift: Key Moments Of The Ongoing Crisis" (2017, June 10) Retrieved 21 December 2018, from https://www.aljazeera.com/news/2017/ 06/qatar-gulf-rift-key-moments-ongoing-crisis-170610042600142.html. 
The dispute occurred due to Qatar's alleged support for Islamist groups such as the Muslim Brotherhood and others backed by Iran. This blockade was both a challenge and opportunity for Qatar to again re-think its food security strategies. First, it put a spotlight on the fragility of the country's food security, showing how reliance on foreign food can be easily disrupted by political disputes. ${ }^{80}$ Second, it revealed that larger financial investment will be needed to keep the economy afloat under such disruption. For instance, Qatar spent over US $\$ 40$ billion to prop up its economy in the midst of the blockade. ${ }^{81}$ These experiences have forced Qatar to become more independent, build stronger international relationships with countries outside of the blockade, and plan for a more sustainable future. ${ }^{82}$

\subsubsection{Food Preference and Waste}

Despite Qatar's inability to produce its own food to meet local population needs, the country's high income and evolving import-substitution has enabled it to achieve a relatively high level of food security. However, food prices have doubled and even rose 10 times higher before the 2017 boycott. This poses a significant challenge to food access for immigrant labourers helping to prepare Qatar for the 2022 FIFA World Cup. In contrast, for most Qatari nationals the problem has been food preferences not price. ${ }^{83}$ Qataris are used to a variety of foods imported from the

80 Irani, Z., "Qatar Blockade Is a Warning to All Desert Countries that Rely on Imported Food" (2017, 4 April) Retrieved 20 December 2018, from http:// theconversation.com/qatar-blockade-is-a-warning-to-all-desert-countries-thatrely-on-imported-food-80283.

81 Sharif, A., "Qatar Injected \$43 Billion to Help Banks after Boycott, S\&P Says" (2018, 20 February) Bloomberg. Retrieved from < https://www.bloomberg.com/ news/articles/2018-02-20/s-p-says-qatar-injected-43-billion-to-help-banksafter-standoff $>$

82 Al Jazeera, "The Siege of Qatar" (2018, 5 June). Retrieved 21 December 2018, from < https://www.aljazeera.com/programmes/specialseries/2018/06/siegeqatar-180603104023939.html >; See also Ulrichsen, K. C., "How Qatar Weathered the Gulf Crisis" (2018, June 11). Foreign Affairs. Retrieved from $<$ https://www.foreignaffairs.com/articles/middle-east/2018-06-11/howqatar-weathered-gulf-crisis $>$

83 Castelier, S., \& Pouré, C., "Made in Qatar: How the Blockade Has Boosted Gulf State's Food Production" (2018, 9 October) Retrieved 20 December 2018, from https://www.middleeasteye.net/in-depth/features/made-qatar-how-theblockade-has-boosted-Gulf\%27s-state-s-food-production-1889951871; See also Walsh, D., "Wealthy Qatar Weathers Siege, but Personal and Political Costs Grow" (2017, December 22) The New York Times. Retrieved from https:// 
global market and have developed specific tastes and quality preferences. ${ }^{84}$ For example, they dislike Turkish milk relative to Saudi milk. ${ }^{85}$ Such peculiar taste and preference is connected to food waste, which has been an increasing problem over the last decade. ${ }^{86}$ Politically, food regulators encourage the disposal of food at earlier dates than necessary. ${ }^{87}$ Culturally, people prefer high quality and blemish-free food, rejecting food for superficial reasons. People also fail to keep food at safe temperatures, leading to early deterioration and spoilage. ${ }^{88}$ These aspects of Qataris life has led to increasing food waste especially among the wealthy. ${ }^{89}$

\section{DISCUSSION AND REFORMS FOR PROGRESSIVE REALIZATION AT THE NATIONAL LEVEL}

Nigeria and Qatar, while having similar oil-based economies and high dependency on food imports, face significantly different political and ecological struggles in their efforts to achieve food security and meet the demands of SDG 2. As the demand for oil drops due to new innovations aimed at addressing climate change, both countries may face new economic crises that could inhibit their ability to pay for food imports. This future threat means both countries have to seek for sustainable ways to achieve food security while overcoming current barriers. To do this, a variety of social, legal, technological, institutional, and political reforms are required. We discuss some of these reforms in the section below.

www.nytimes.com/2017/07/02/world/middleeast/qatar-saudi-arabiablockade.html

84 Castelier, S., \& Pouré, C. (2018).

85 Walsh, D., "Wealthy Qatar Weathers Siege, but Personal and Political Costs Grow" (2017, December 22) The New York Times. Retrieved from https:// www.nytimes.com/2017/07/02/world/middleeast/qatar-saudi-arabiablockade.html.

86 Adema, S., "Food Waste Woes in Qatar" (2016, March 9) Retrieved December 22, 2018, from < https://www.ecomena.org/food-waste-in-qatar/>; See also Irani, Z., "Qatar blockade is a warning to all desert countries that rely on imported food" (2017, April 4) Retrieved 20 December 2018, from < http:// theconversation.com/qatar-blockade-is-a-warning-to-all-desert-countries-thatrely-on-imported-food-80283>

87 Irani, Z. (2017).

88 Adema, S. (2016).

89 Irani, Z. (2017); See also Adema, S. (2016). 


\subsection{Implementing Social and Institutional Reforms}

Food security is vital to the economic and political stability of any country. SDG 2 offers Nigeria and Qatar a fresh opportunity to create new governance architectures to boost agricultural productivity and improve food security strategies. It emphasizes the need to use a mix of market incentives, agricultural financing, seed distribution programmes, vulnerability assessment, institutional redesign and technological innovations. In doing so, SDG 2 seeks to end hunger and ensure the availability, accessibility and affordability of nutritious and sufficient food for all people..$^{90}$ In the case of Qatar, the government has already taken measures to revitalize its national food programmes through strategic shifts from trade-based food policy to increased support for selfsufficiency. After the 2017 blockade, Qatar adopted two policy frameworks: the Qatar National Vision 2030 (QNV 2030) and Qatar Second National Development Strategy (2NDS). ${ }^{91}$ The 2NDS stresses self-reliance on a variety of issues, ranging from food and medicine to national security. ${ }^{92}$ Within this framework, Qatar has a variety of plans in place to increase food and water sustainability as well as accelerate local agricultural innovation using soil-free greenhouse farming systems and recycled irrigation water. Qatar also aims to grow up to 70 per cent of its own vegetables by $2030 .{ }^{93}$ In addition to increasing national food production, Qatar has opened new trade routes with Iran, Turkey, and Pakistan thereby diversifying its food import profile. ${ }^{94}$

In the case of Nigeria, the government has established a multi-layer and multi-cluster institutional framework for enhanced coordination on

90 United Nations, "Sustainable Development Goals Report 2016" (2016) < https:/ /unstats.un.org/sdgs/report/2016/> (accessed March 16, 2017).

91 Reuters, "Facing Boycott, Qatar Focuses on Self-Reliance in Five-Year Plan" (2018 14 March) Retrieved from < https://www.reuters.com/article/us-qatareconomy-plan-idUSKCN1GQ29S > ; See also Ministry of Development Planning and Statistics, "Qatar Second National Development Strategy 2018-2022" (2018) Gulf Publishing and Printing Company. Retrieved from www.mdps.gov.qa.

92 Ministry of Development Planning and Statistics (2018).

93 Doha News, "Soil-Free Greenhouses to Help Qatar Grow Up to 70\% Of Its Veg by 2023 " (2015, August 25) Retrieved from < https://dohanews.co/soil-freegreenhouses-to-help-qatar-grow-up-to-70-of-its-veg-by-2023/>

94 Castelier, S., \& Pouré, C., "Made in Qatar: How the Blockade Has Boosted Gulf State's Food Production" (2018, 9 October) Retrieved 20 December 2018, from https://www.middleeasteye.net/in-depth/features/made-qatar-how-theblockade-has-boosted-Gulf\%27s-state-s-food-production-1889951871 
SDGs mainstreaming. A Senior Special Assistant to the President (SSAP) on SDGs and an Inter-Ministerial Committee have been established to guide and coordinate engagement with government ministries, departments, and agencies to ensure horizontal and vertical coherence between SDGs and other development policies and strategies. ${ }^{95}$ There are also several federal policies and programme drivers aimed at SDG 2. These include the Green Alternative Promotion Policy; Incentive-BasedRisk Sharing System for Agricultural Lending; Rural Finance Institution Building Programmes; Commercial Agricultural Credit Scheme; and so on. In addition, there are two civil society policy initiatives - the Zero Hunger Programme and the Savings Internal Loan Schemes. ${ }^{96}$ While these efforts are commendable, corruption, political instability, economic recession, and lack of harmonization are major roadblocks to proper implementation. Moving forward, Nigeria needs a clear strategic plan on SDG 2, such as an Integrated National Food Security Strategy (IFSS) and action plan. An IFSS can help a country identify the key nutritional needs of its citizens and key actions to improve food security such as reliable and inclusive data on food and agricultural programmes; expansion of irrigation and land tenure security especially for women and other small-scale farmers; adoption of procedural and rights-based mechanisms to increase awareness and participation in food production programmes; and removal of political barriers and policies that stifle agriculture, distort food prices, and increase local vulnerabilities to hunger and poverty.

\subsection{Adapting Technological Innovation to Meet Local Needs}

Qatar's technological advancement and investment in local infrastructure has allowed the country to increase local food production despite having limited arable land, less manpower, and severe climatic constraints. The government also emphasizes the sustainable management of fisheries and the development of aquaculture to meet national demand. Qatar plans to develop alternative and efficient feedstocks to boost the livestock industry. Regulation and financial support have also been put in place to

95 Federal Republic of Nigeria, "Implementation of the SDGs: A National Voluntary Review" (2017) https://sustainabledevelopment.un.org/content/documents/ 16029Nigeria.pdf.

96 Federal Republic of Nigeria (2017). 
improve the quality and quantity of livestock production. On water security, Qatar hopes to improve the efficiency of agricultural and domestic water use through social awareness programmes and modern technology and regulations. ${ }^{97}$ Nationalist sentiments toward local food consumption and purchasing have also emerged since the 2017 blockade. Many people now buy food made in Qatar, thus increasing the profitability and viability of local industries. Early endeavours into hydroponics to expand local food production have been promising and the government remains committed to these technological and policy fixes. ${ }^{98}$

Nigeria, incongruously, has large tracts of arable land and significant manpower but limited infrastructure and modern technology to increase agricultural production and yields. If SDG 2 is to be met by 2030, Nigeria will need substantial increases in agricultural investments and infrastructure, including extensions, credit, improved road, and transportation systems. Farmers also need more support from public and private institutions to meet the demand for irrigation technology, training, education, supply tools, seeds, fertilizers, storage facilities, tax subsidies, and other solutions that address local food challenges. ${ }^{99}$

\subsection{Reforming Property Laws and Protecting Land Rights}

Qatar has strong laws that protect property and ownership of land. The Qatar Law No. (14) of 1964 establishes the property system and land title in Qatar, while Law No. (13) of 1988 allows the government to expropriate land for public use. However, this is not a common practice and when it happens, owners receive fair compensation in return. In the case of Nigeria, the Land Use Act of 1978 vests absolute ownership, management, and control of land in each state of the federation of Nigeria in the Governor, leaving individuals with "rights of occupancy". ${ }^{100}$

97 Ministry of Development Planning and Statistics, "Qatar Second National Development Strategy 2018-2022" (2018) Gulf Publishing and Printing Company. Retrieved from <www.mdps.gov.qa>

98 Mustafa, S.A.-A., "Growing food pyramids in the sand: how sustainable are Qatar's self-sufficiency and foreign agro-investment policies?" (2017) Journal of Agriculture and Environment for International Development 2(111), 409-424.

99 Eme, O. I., Onyishi, A. O., Uche, O. A., \& Uche, I. B., Eme, O. I., Onyishi, A. O., Uche, O. A., \& Uche, I. B., "Food insecurity in Nigeria: A Thematic Exposition" (2014) Arabian Journal of Business and Management Review (OMAN Chapter), 4(1), 1.

100 The Nigerian Land Use Act, (1978) < http://www.nigeria-law.org/Land\%20 Use\%20Act.htm> 
Furthermore, the Act allows for appropriation of land for public purposes. This provision is frequently exploited by the government and has allowed for the arbitrary confiscation of communal and tribal lands and the acceleration of land grabs in the country, thus posing a major threat to subsistence farmers. For example, indigenous groups and female farmers face significant legal hurdles to maintaining their rights vis-a-vis state policies and development processes that hand over land to big businesses. Land grabbing robs people of their access to land and water and undermines their livelihoods and food security. ${ }^{101}$ To progressively achieve SDG 2, Nigeria will need to reform current land laws and also adopt new legislative framework and policies that protect the rights of subsistence farmers, especially women farmers, from land dispossession.

\subsection{Improving Local and Geopolitical Conflict Resolution Mechanisms}

Concerns about food security in both Nigeria and Qatar heightened with the sudden outbreak of conflicts. Internal conflicts involving Fulaniherders as well as the Boko Haram insurgence in northern Nigeria affected food production, availability, and prices across the country. Reduced food access also compounded other forms of grievance and discontent, such as poverty, unemployment, and marginalization. Similarly, when fifteen countries led by Saudi Arabia severed diplomatic ties with Qatar, the effect of this on food availability and price was swift and dramatic. So, as Nigeria and Qatar look into the future to realize the SDGs, it will be important to address such conflict-induced food insecurity. Measures that can be taken include improving conflict resolution mechanisms at different political scales; promoting peacebuilding programmes among communities, groups and countries; de-politicizing food structures; combining efforts to ensure resilient livelihoods; investing in agriculture to prevent the cycle of conflict; and working to achieve sustained peace.

\section{CONCLUSION}

This article has presented a holistic analysis of food security and sustainable agricultural goals (SDG 2) within a broader political economy

101 Attah, N. E., "Possession by Dispossession: Interrogating the New Wave of Land Grabbing in Nigeria" (2013) Journal of Land and Rural Studies, 1(2), 213-228. 
and political ecology context focusing on Nigeria and Qatar as case studies. It discussed some of the multi-scale factors that undermined MDG 1 and showed how global restructuring of seed ownership, unequal trade, conflict, weak property regimes, and commodity market price volatility all made the achievement of zero-hunger an unrealized goal in many developing countries. Drawing on the Nigeria and Qatar case studies, we argue that SDG 2 offers developing countries a fresh opportunity to reassess and revitalize the national architecture on sustainable agriculture as well as address existing political, ecological, technological, social and geopolitical barriers that undermine food security. At the national level, Qatar will need to continue to improve on technological solutions, reduce food waste, expand trade relations and agricultural investments, and support regional efforts on conflict resolution. In the case of Nigeria, renewed efforts are required to address the inadequate protection of smallholder farmers, confiscation of land, technological gaps, internal conflicts, food safety and the lack of institutional coordination on agricultural and food problems. Options that could help include establishing IFSS and national laws that protect people's right to food, including the rights of subsistence farmers, particularly women and indigenous people.

There is also a need to establish legal and social frameworks that enhance harmonization and coordination among different agencies, ministries and departments charged with food and agricultural responsibilities. Governments will also need to mobilize necessary private sector financing and capacity to boost investment in the agricultural sector. Public-private partnership programmes on agriculture can promote direct private sector investment in agricultural programmes as well as rural microfinance schemes that could facilitate small-scale farmers' access to credit. Finally, transformation is required from local to global scales, and this will include creating new models of governance that address the linkages between food security, agriculture, water, and other development matrices that are critical to the realization of SDG 2 . 